\title{
Nemedikamentiniai bronchų sekreto šalinimo metodai sergant cistine fibroze
}

\author{
Virginija Kalinauskaitė, Kęstutis Malakauskas \\ LSMU MA Pulmonologijos ir imunologijos klinika
}

Reikšminiai žodžiai: cistinė fibrozė, kvėpavimo takai, fizinės terapijos metodai.

Santrauka. Straipsnyje aptariami nemedikamentiniai bronchų sekreto šalinimo metodai sergant cistine fibroze (CF). Jie skiriami i aktyvių paciento pastangų reikalingus ir nereikalingus metodus. Kai CF eiga stabili, prioritetiniai - aktyvių paciento pastangu reikalingi metodai, o CF paūmëjus vyrauja aktyvių pastangų nereikalingi metodai.

Cistinè fibrozè (CF) - tai genetinè, autosominiu recesyviniu būdu paveldima liga, pasireiškianti daugelio organizmo sistemų sutrikimu, sąlygotu egzokrininiu liauku funkcijos pažeidimo. Dažniausiai sutrinka plaučių funkcija dèl kvėpavimo takuose susidarančio tiršto, klampaus sekreto bei sunkesnio jo pasišalinimo (1 pav.). Kliniškai pasireiškia užsitęsęs kosulys (dažnai su skrepliavimu), dusulys, neịprastai sūrus prakaitas, pasikartojančios bei ilgai trunkančios kvėpavimo takų infekcinès ligos. CF ligonius galima atskirti ir iš būdingos išvaizdos - jauni mažo svorio ir dèl sulètejusio augimo nedidelio ūgio asmenys „būgno lazdeliụ" pirštais bei "laikrodžio stikliuko" nagais. Pasaulinès sveikatos organizacijos duomenimis, Europoje CF serga 1 iš 2000-3000 naujagimių, tačiau dèl sunkios ligos eigos suaugusiųjų amžiaus sulaukia nedaugelis.

\section{CISTINĖS FIBROZĖS SUKELIAMO PLAUČIŲ PAŽEIDIMO PATOGENEZĖ}

CF atvejais VII chromosomoje randama transmembraninị potencialą reguliuojantị baltymą (CFTR) koduojančio

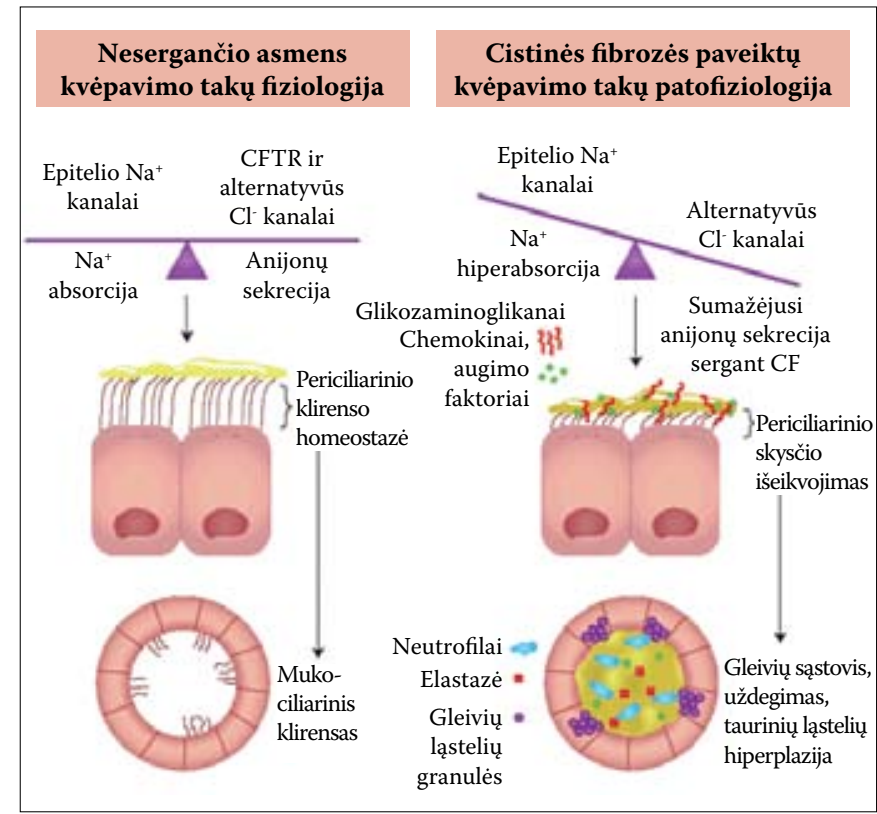

2 pav. Cistine fibroze sergančio ir nesergančio asmens virpamojo epitelio pokyčiai
Cistinès fibrozès paveikiami organai

Sinusai: sinusitai (infekcinės kilmės)

Plaučiai: kvèpavimo takai pasidengia storu tirštų, lipnių gleivių sluoksniu ir išplatẻja; dažnos bakterinès infekcijos

Oda: prakaito liaukos išskiria koncentruotą, sūrụ prakaitą

Kepenys: užsikemša tulžies latakai

Kasa: užsikemša kasos latakai

Žarnynas: sutrinka maisto medžiagų pasisavinimas

Reprodukcijos organai: nuo lytinio vystymosi sutrikimų, dismenorejos, amenorëjos, spermos kanalų obstrukcijos iki nevaisingumo
B

Nesergančio asmens kvèpavimo takai
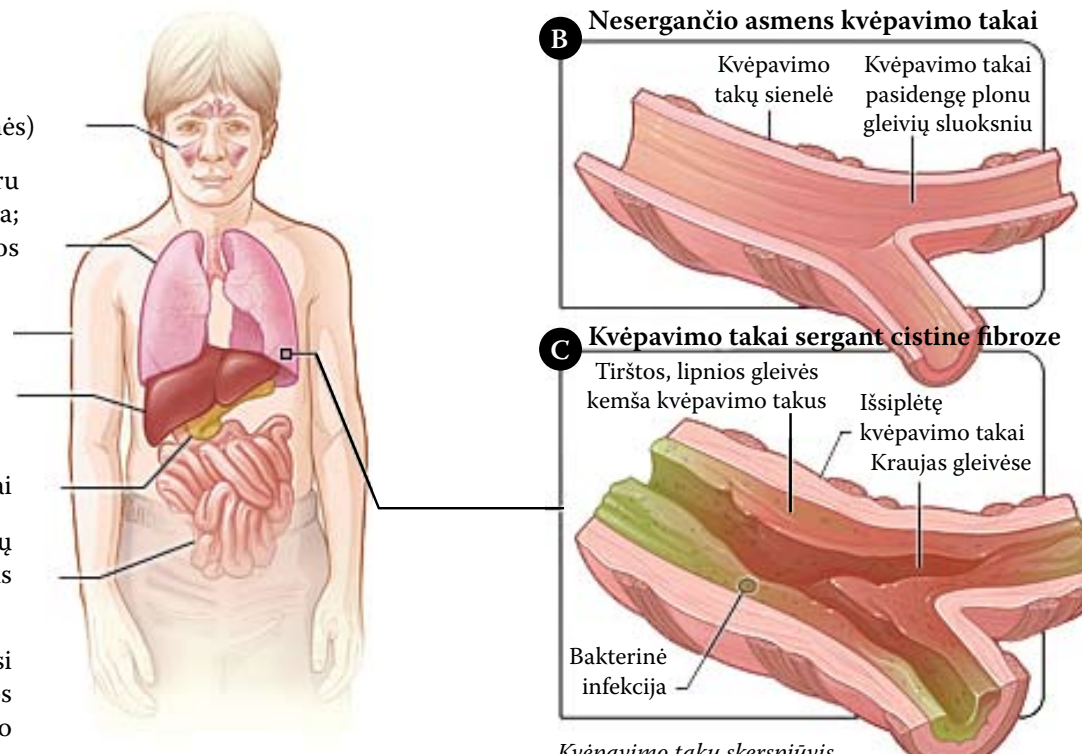

C Kvèpavimo takai sergant cistine fibroze Tirštos, lipnios gleivès kemša kvèpavimo takus Išsiplètę kvejpavimo takai

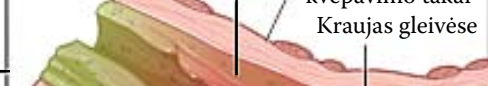
Nor Bakterinè infekcija -

Kvèpavimo taku skerspjūvis 
geno mutacija. Šis genas reguliuoja chloro, natrio, bikarbonatų ir kitų jonų kanalų funkciją, taip pat ịvairius kitus ląstelèse vykstančius procesus. Esant jo mutacijai, sutrinka liaukų latakèlių epitelio chloro kanalu funkcija. Tai lemia gleivių sutirštėjimą ìvairiuose organuose.

CFTR baltymas veikia kaip chloro jonų kanalas, per kurị jonai iš ląstelès patenka i tarpląstelinị skystị (sumažeja chloro ir natrio reabsorbcija prakaito liaukose, todèl prakaite padideja chloro ir natrio kiekis, sumažèja chloro sekrecija ị kvẻpavimo takus). Dèl šio baltymo geno mutacijos, sutrinka chloro jonų sekrecija per epitelinę membraną - sukuriamas osmosinis gradientas, dèl kurio mažiau vandens patenka i paviršinị epitelio sluoksni. CFTR baltymas slopina ir natrio absorbciją. Stingant jo, per epitelio natrio jonu kanalus absorbuojama pernelyg daug natrio ir vandens. Taip išeikvojamas kvėpavimo taku paviršiuje esančio vandens kiekis, gaminamos gleivès tampa labai tirštos, pamažu tirštėja bronchų sekretas, kuris darosi labai koncentruotas, pažeidžiamos kvėpavimo takų epitelio blakstienèlès ir sutrikdomas mukociliarinis klirensas (2 pav.) - visa tai sukelia sekreto sąstovi kvėpavimo takuose. Kai kuriems ligoniams sutrinka bikarbonatų jonų pernaša, todèl sumažèja išskiriamų gleivių $\mathrm{pH}$ (padidèja rūgštingumas). Tai lemia padidejjusią gleivių precipitaciją ir gleivių kamščių susidarymą.

Dèl sutirštejusio sekreto ir lètesnio jo pasišalinimo apatiniuose kvèpavimo takuose linkę telktis patogeniniai mikroorganizmai, sukeliantys dažnas ir ilgai besitęsiančias kvėpavimo takų infekcines ligas. Bronchų gleivinę infiltruoja polimorfonukleariniai fagocitai. Uždegimo ląstelès (neutrofilai, makrofagai) ir bakterijos išskiria proteolizinių fermentų, ardančių bronchų jungiamąji audinị. Atsiranda negrịžtamų struktūrinių kvẻpavimo takų pokyčių: bronchektazès, virpamojo epitelio metaplazija i daugiasluoksni plokščiąjị, fibrozè.

\section{PROBLEMA}

Vienas aktualiausių uždavinių, gydant CF sergantị asmenị, - pagerinti tiršto, klampaus sekreto pasišalinimą iš kvẻpavimo takų. Sveiko žmogaus kvėpavimo takuose esantis virpamasis epitelis padeda sekreto drenažui vykti savaime, be jokių papildomų priemonių, todèl kvėpavimas esti normalus. CF sergančiam pacientui reikalinga pagalba, kuri priklauso nuo ligos eigos konkrečiu metu (iprasta eiga ar paūmèjimas). Kai liga stabili, pacientas gyvena îprastinị gyvenimą, reguliariai atlieka mankštą, daugiausia krūtinès ląstai treniruoti, papildydamas ją kvépavimo pratimais bei ịvairiais fizinès terapijos metodais, kurių pasirinkimas dabar yra didelis. Ligai paūmèjus, kai kurie metodai gali būti žalingi, todèl svarbu prieš skiriant kvėpavimo takų sekreto pasišalinimą gerinančias procedūras, tinkamai ịvertinti klinikinę situaciją.

\section{METODAI, GERINANTYS SEKRETO PASIŠALINIMĄ}

Daugelio ligu atveju pirmenybè teikiama medikamentiniam gydymui, neretai tuo ir apsiribojama, o CF ligoniui laiku neskyrus tinkamo nemedikamentinio gydymo beveik neįmanoma išvengti ligos paūmèjimo bei spartaus būklès blogèjimo ar pasiekti gerų gydymo rezultatų. Gydančiojo gydytojo tikslas - trumpinti susidarančio tąsaus, klampaus sekreto buvimo kvejpavimo takuose laiką, gerinti jo pasišalinimą, retinti ligos paūmejjimus, išlaikyti kiek įmanoma geresnę plaučių funkciją bei fizinio krūvio toleravimą. Tai pasiekti galima taikant ịvairius bronchų sekreto pasišalinimą gerinančius metodus (lentelè) atskirai ar derinant tarpusavyje bei tinkamai gydant vaistais. Kokias procedūras pasirinkti konkrečiu atveju, sprendžia gydytojas, visapusiškai ịvertinęs paciento bendrąją būklę, ligos eigą (ịprasta eiga ar paūmèjimas), esamas ar galimas komplikacijas.

\section{Aktyvių paciento pastangų reikalingi bronchų sekreto šalinimo būdai}

Taikomi aktyviems, kliniškai stabilios būklès CF ligoniams, o esant CF paūmèjimui, ypač sunkiam, - rečiau.

Fizinis aktyvumas. Viena dažnesnių fizinio aktyvumo formų - aerobikos pratimai; efektyvūs ir rekomenduojami visiems funkciškai pajègiems CF ligoniams. Pratimai atliekami tiek individualiai, tiek grupemis, bet veiksmingesni individualūs užsièmimai - geriau perprantama pratimų technika, mažesnè tikimybè patogeniniais mikroorganizmais užkrèsti kitą ar užsikrèsti pačiam. Aerobikos programos turi būti sudaromos kiekvienam asmeniui individualiai pagal bendrąją būklę, fizinị pajègumą, krūvio toleravimą, gretutines ligas. Svarbu stiprinti ir širdies bei kraujagyslių sistemą, užsièmimų metu skatinti pacientų savarankiškumą, saviraišką ir taip didinti pasitikejjimą savimi. Vien tinkamas fizinis aktyvumas pagerina savijautą, tačiau kartu taikant ir kitas sekreto pasišalinimą skatinančiais priemones, rezultatas būna akivaizdesnis ir greitesnis, nors ir trumpalaikis. Norint, kad poveikis truktu ilgiau, pratimus bei kitus pasirinktus sekreto pasišalinimą skatinančius metodus reikia taikyti reguliariai, nepertraukiamai. Kasdien monotoniškai daromi fiziniai pratimai vargina pacientą, mažina motyvaciją juos reguliariai ir kokybiškai atlikti, dèl to nukenčia jų efektyvumas. Dèl šios priežasties CF ligoniams reikalinga artimųjų pagalba, kuriant aktyvios gyvensenos modeli šeimoje bei fizini aktyvumą integruojant $\mathfrak{i}$ kasdienę veiklą. Pastebètas gana stiprus ryšys tarp reguliariai atliekamų fizinių pratimų ir geros plaučių funkcijos išsilaikymo.

Fizinis aktyvumas CF ligoniams dažnai asocijuojasi su pabodusia mankšta fizioterapijos salejje, palatoje ar namuose, visgi fizinis aktyvumas gali būti labai ịvairus - tai ir pasivaikščiojimas, išvykos i gamtą, orientacinis sportas, plaukiojimas baidaremis, dviračio mynimas, tre- 
Lentelè. Sekreto iš kvèpavimo takų pasišalinimą gerinantys metodai

\begin{tabular}{|c|c|c|}
\hline \multicolumn{2}{|c|}{ Fizinès terapijos metodai } & \multirow{2}{*}{$\begin{array}{l}\text { Pastabos } \\
\text { Vien mankšta reikšmingai plaučių funkcijos nepagerina, tačiau gerina bendrąją } \\
\text { paciento savijautą }\end{array}$} \\
\hline $\begin{array}{l}\text { Reikalingi aktyvių } \\
\text { paciento pastangų }\end{array}$ & Fizinis aktyvumas & \\
\hline & Aktyvus kvėpavimas & $\begin{array}{l}\text { Nereikia jokios įrangos } \\
\text { Tinka bet kurio amžiaus ligoniui }\end{array}$ \\
\hline & $\begin{array}{l}\text { Iškvejpimas naudojant vibraciją sukeliantị } \\
\text { PEEP prietaisą }\end{array}$ & $\begin{array}{l}\text { Padeda atpalaiduoti sekretą } \\
\text { Didina pasišalinančio sekreto tūrị } \\
\text { Paprasta atlikti savarankiškai } \\
\text { Padeda kosint išvengti slègio svyravimų plaučiuose }\end{array}$ \\
\hline & Autogeninis drenažas & $\begin{array}{l}\text { Itin tinka esant bronchų hiperreaktyvumui, nes išvengiama kosulio ir kvėpavi- } \\
\text { mo takų užsidarymo } \\
\text { Reikia motyvacijos ir susikaupimo } \\
\text { Sunku atlikti jauniesiems pacientams } \\
\text { Savarankiškai atliekama procedūra }\end{array}$ \\
\hline \multirow{5}{*}{$\begin{array}{l}\text { Nereikalingi aktyvių } \\
\text { paciento pastangų }\end{array}$} & Krūtinès ląstos perkusija & \multirow{2}{*}{$\begin{array}{l}\text { Pozicinio drenažo ir krūtinès ląstos perkusijos pagrindinis tikslas - pagreitinti } \\
\text { sekreto pasišalinimą iš kvėpavimo takų veikiant gravitacinei jègai (itin veiks- } \\
\text { minga pacientams, turintiems bronchektazių) } \\
\text { Veikiant nustatytus pozicinius taškus pagerinamas sekreto šalinimas iš ịvairių } \\
\text { plaučių vietų }\end{array}$} \\
\hline & Pozicinis drenažas & \\
\hline & $\begin{array}{l}\text { Kosulio reflekso sukèlimas naudojant } \\
\text { "kosulio asistentą" }\end{array}$ & $\begin{array}{l}\text { Kosulio refleksą sukelia slègių skirtumai } \\
\text { Saugu }\end{array}$ \\
\hline & Aukšto dažnio krūtinès ląstos vibracija & $\begin{array}{l}\text { Reikalinga slaugytoja, padedanti atlikti šią procedūra } \\
\text { Krūtinės suvaržymo pojūtis, sunku įkvèpti } \\
\text { Nerekomenduojama sunkiai sergantiems CF ligoniams }\end{array}$ \\
\hline & Mechaninè aspiracija & Paprastai taikomi paūmèjimo metu, kai neefektyvios neinvazinès priemonès \\
\hline
\end{tabular}

PEEP - prietaisai, sukuriantys teigiamą slègị iškvejpimo pabaigoje

niruotès ant bėgimo takelio, šokių pamokos, maudynės, plaukiojimas vandens paviršiuje, naudojant kvèpavimui skirtą vamzdeli ir t. t., tačiau yra keletas sporto šakų, kurios sergant šia liga gali būti labiau žalingos nei naudingos:

- kontaktinis sportas (kovos menai, regbis);

- nardymas su akvalangu (nepatartinas dèl pneumotorakso rizikos);

- jodinejjimas tampa rizikingas, jei kartu atliekamas ir žirgu prižiūrètojo darbas, susijęs su didele tikimybe ikvèpti grybelių sporų;

- treniruotès su sunkiais svoriais pavojingos tiems pacientams, kurie turi implantuotus veninius kateterius ir rizikuoja igyti išvaržą kateterio vietoje.

Prieš pasirenkant vieną ar kitą sporto rūší, pacientas turètų apsilankyti pas ji gydanti gydytoją ir atlikti reikalingus tyrimus širdies ir plaučių būklei įvertinti.

Mankšta, derinama su kitais fizinès terapijos metodais, turi būti atliekama bent vieną kartą (rekomenduojama du tris kartus) per dieną, priklausomai nuo simptomų.

Aktyvus kvèpavimas - tai fizinès terapijos metodas, kai cikliškai kartojamas kvėpavimas įvairia technika: kvèpavimo kontrolè $\rightarrow$ krūtinès ląstos išplètimas $\rightarrow$ kvėpavimo kontrolè $\rightarrow$ stiprus iškvèpimas su jèga (3 pav.), atliekamas nepertraukiamai fizioterapeuto re-

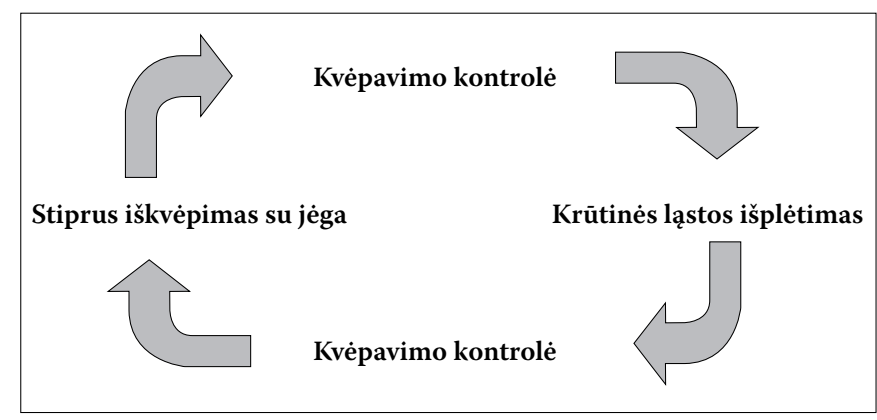

3 pav. Aktyvus kvėpavimo ciklas

komenduotą laiką (paprastai keletą kartų arba trumpiau, jei pacientas pavargsta). Aktyviu kvėpavimu siekiama $\mathrm{CF}$ ligoniui padèti produktyviau atsikosèti, nesukeliant hipoksemijos pavojaus ar bronchų obstrukcijos.

Pirmasis pratimas vadinamas kvejpavimo kontrole: kvėpuojama nuleidus pečius, atsipalaidavus, iprastai, ramiai, apatine krūtinès ląstos dalimi ir pilvu (vadinamasis pilvinis kvejpavimas). Pratimas atliekamas ne tik kaip sudedamoji aktyvaus kvépavimo ciklo dalis, bet ir kaip atpalaiduojantis pratimas tarp kitú fizinès terapijos procedūrų, leidžiantis pailsèti kvèpuojamiesiems raumenims. Po kvėpavimo kontrolès daromi krūtinès ląstos išplètimo pratimai: giliai įkvèpus pro nosị i krūtinès ląstą, 


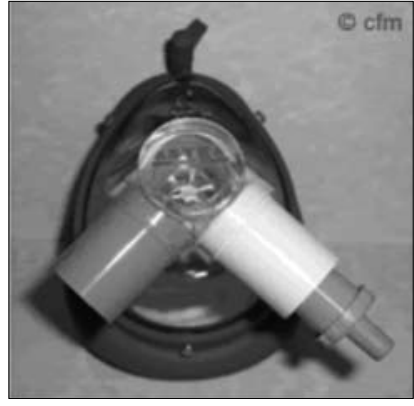

4 pav. PEEP prietaisas su kauke http://www.cfmedicine.com/htmldocs/ CFText/physiotherapy.htm

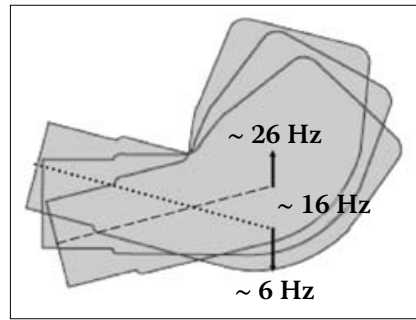

6 pav. PEEP prietaiso sukeliamos vibracijos dažnis priklausomai nuo laikymo kampo

http://www.cfww.org/docs/ipg-cf/bluebook bluebooklet2009websiteversion.pdf

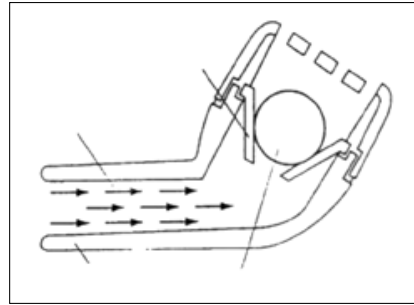

8 pav. FLUTTER prietaiso

mechanizmas

http://www.passthefracp.com/Physio\%20 for\%20doctors.htm

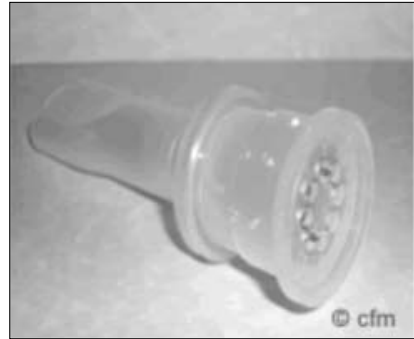

5 pav. Kandiklio formos PEEP prietaisas

http://www.cfmedicine.com/htmldocs/ CFText/physiotherapy.htm

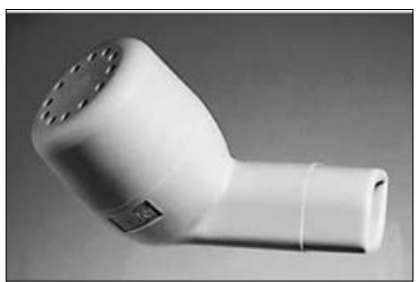

7 pav. FLUTTER prietaisas

https://secure.c8.hostexcellence.com/products/index.php?main_page = product infoEproducts $i d=191$ Ezenid $=6 r s p 4 l 0 r 9$ smd3ns6j5f2gdqdi3

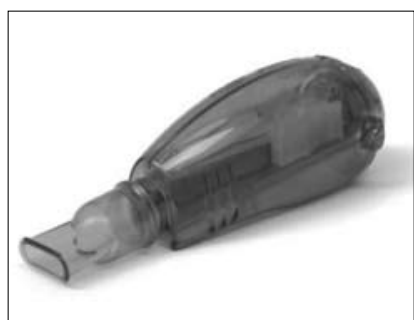

9 pav. $A C A P E L L A^{\circledast}$ prietaisas

http://www.cfmedicine.com/htmldocs/ CFText/physiotherapy.htm

oras sulaikomas keletui sekundžių ir ramiai iškvepiamas pro burną. Kartojama 3 ar 4 kartus. Atsipalaidavimui - vèl kvėpavimo kontrolès pratimas. Per šiuos tris kvėpavimo etapus iš smulkiųjų kvèpavimo takų skatinamas išjudèti sekretas. Ciklas baigiamas forsuotu iškvèpimu: stipriai, su jèga iškvepiamas oras pro plačiai atvertą burną - taip susikaupęs sekretas skatinamas judèti iš smulkiųjų bronchų i stambiuosius ir pasišalinti. Vienas ar du stiprūs iškvėpimai derinami su kvẻpavimo kontrole, kad pacientas nepavargtų ir išlaikytų reikalingą tempą. Ciklas kartojamas.

Vaikai šios kvėpavimo technikos mokomi nuo dvejų metu (arba individualiai nuo tada, kai pradeda suvokti). Svarbiausias veiksmas - forsuotas iškvèpimas. Priklausomai nuo plaučių tūrio, kuriuo atliekamas pūtimas, valosi skirtingi kvėpavimo takai. Didelio oro tūrio iškvėpimas (kai iškvepiant dalyvauja krūtinès ląsta) padeda šalinti

sekretą iš viršutinių, vidutinio ar mažesnio tūrio - iš apatinių, labiau periferinių kvejpavimo takų.

Aktyvaus kvèpavimo ciklas gali būti atliekamas bet kokioje padètyje: seddint, gulint ant nugaros, ant šono, ant pilvo (priklauso nuo to, kokioje padètyje atsikosejjimo efektas būna geriausias). Jis derinamas su poziciniu drenažu, krūtinès ląstos perkusija ir vibracija (kvėpavimo kontrolès etapas derinamas su perkusija; krūtinès ląstos išplètimas - su vibracija išvėpimo metu, o iškvėpiant forsuotai nereikia nei vibracijos, nei perkusijos).

Prietaisai, sukuriantys teigiamą slègi iškvèpimo pabaigoje (PEEP prietaisai) (4, 5 pav.). Teigiamas slègis iškvépimo fazèje naudojamas siekiant atverti smulkiuosius kvėpavimo takus ir neleisti jiems subliūkšti, palengvinti oro cirkuliaciją juose ir gerinti tąsaus, klampaus sekreto pasišalinimą.

Iškvėpimas taikant lengvą pasipriešinimą $(10-20 \mathrm{~cm}$ vandens stulpelio) sudaro geresnes sąlygas judèti sekretui iš kvėpavimo takų, ypač iš smulkiųjų bronchų, nes sukuriamas slègis neleidžia pastariesiems subliūkšti ir taip susiaurinti broncho spindžio, kas trukdo sekretui judèti. Prietaisai yra labai paprasti naudoti, todèl nereikia medicinos personalo pagalbos. Galima rinktis iš kelių rūšių: kaukès ar kandiklio pavidalo; kuris iš jų tinkamesnis/praktiškesnis, kol kas neišsiaiškinta. Kai pacientui nusprendžiama skirti ši PEEP prietaisą, parenkamas vienas iš aštuonių galimų pasipriešinimo variantu (skersmuo nuo 1,5-5 mm) 10-20 $\mathrm{cm}$ vandens stulpelio slègiui vidurinèje iškvėpimo fazèje sukelti. Pasipriešinimas reguliariai matuojamas manometru. Procedūra atliekama sẻdimoje ar pozicinio drenažo padètyje. Svarbus kvejpavimo dažnis, aktyvus iškvėpimas pro veido kaukę ar kandiklį. Metodas paprastai taikomas po pūtimo, kosèjimo ir kvėpavimo kontrolès procedūrų. Ciklas kartojamas tiek kartų, kiek reikia pasiekti maksimaliam sekreto valymuisi iš kvèpavimo takų.

Gali būti derinamas ir su kitais fizinès terapijos metodais.

Vibraciją sukeliantis PEEP prietaisas - tai patobulintas iprastinis PEEP prietaisas, sukeliantis pasipriešinimą iškvepiamam orui sukurdamas jo virpesius. Šie veiksniai skatina išjudeti kvėpavimo takuose susikaupusi sekretą bei spartina jo pasišalinimą. Jis itin efektyvus kenčiantiems nuo gausesnès tiršto, tąsaus sekreto gamybos ir sutrikusio jo šalinimo iškvėpimo metu dèl per anksti subliūkštančių kvẻpavimo takų. Paprasta naudoti bet kurio amžiaus pacientams tiek medicinos istaigose, tiek namuose, nereikalinga medicinos personalo pagalba, todèl neribojamas savarankiškumas. Procedūra atliekama patogioje padètyje (paprastai sèdint), kvėpuojant ịprastai ir išpučiant orą i vibracines bangas sukelianti prietaisą. Keičiant priemonès laikymo kampą (6 pav.), galima sunkinti ar lengvinti sukuriamą pasipriešinimą (keliant didesniu kampu nei $90^{\circ}$, matuojant nuo krūtinès ląstos, procedūra sunkinama, mažiau nei $90^{\circ}$ - lengvinama). 


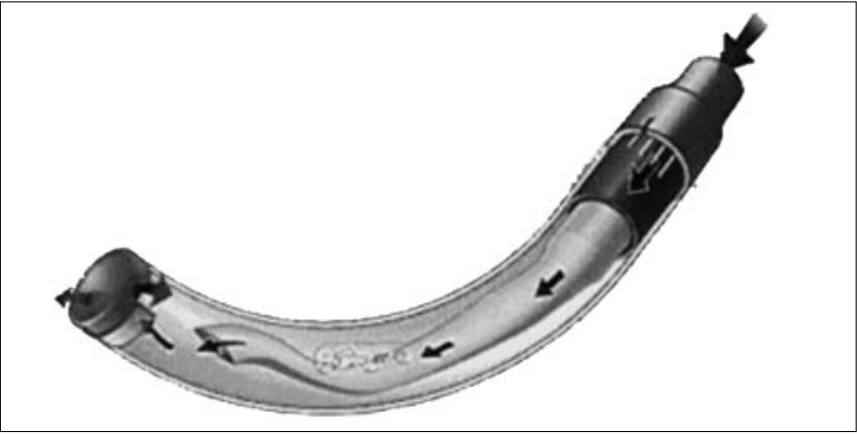

10 pav. RC-Cornet prietaisas

http://www.sciencedirect.com/science/article/pii/S1526054207000085

Vibraciją sukeliantys PEEP prietaisai paprastai neskiriami pacientams, kuriems buvo îvykęs spontaninis pneumotoraksas, kuriems radiologiniu tyrimu nustatyta plaučių pūslių (bulų), turintiems ausies būgnelio perforaciją.

Vibraciją sukeliančių PEEP prietaisu yra keletas: FLUTTER, ACAPELLA, RC-Cornet ${ }^{\oplus}$, RC-Cornet-N ${ }^{\bullet}$. Lietuvoje dažniau naudojami FLUTTER ir ACAPELLA.

FLUTTER $^{\odot}$ (7, 8 pav.) - mažas iš plastiko pagamintas prietaisas, korpuse turintis dideli iškvepiamo oro srovės judinamą metalinị rutulị. Dẻl staigių išpučiamos oro srovès sukuriamų trūkinejjimų/vibracijų sukeliamo kontroliuojamo teigiamo vibracinio spaudimo gerèja kvèpavimo takuose esančio sekreto drenažas. Prietaisas gali būti naudojamas tik vertikalioje padètyje; nuo laikymo kampo priklauso sukeliamų vibracijų dažnis. Procedūra atliekama dešimties-penkiolikos iškvépimų serijomis su kvèpavimo kontrolès (skirtos atpalaiduoti kvėpuojamuosius raumenims) pratimais tarp jų. Pratimo trukmé 15-20 min. su pertraukomis, priklausomai nuo paciento poreikių ir galimybiuc. Vibraciją sukeliantys prietaisai gali būti naudojamai tiek kaip sudedamoji, tiek kaip savarankiška fizinès terapijos dalis.

ACAPELLA $^{\oplus}$ (9 pav.) - vibraciją sukeliantis PEEP prietaisas su nustatomu pasipriešinimo lygmeniu, nepriklausomu nuo prietaiso laikymo padèties. Dèl to ACAPELLA, priešingai nei FLUTTER, patogus naudoti ir pozicinio drenažo padètyse, nesukeliant pacientui nepatogumo ir nesumažinant gydymo efektyvumo.

Jei vibraciją sukeliančiais prietaisais nepavyksta išprovokuoti produktyvaus kosulio, šią procedūrą reikètų derinti su stipriu iškvėpimu atvira burna bei kitais fizinės terapijos metodais.

RC-Cornet ${ }^{\oplus}$ ir RC-Cornet- $\mathrm{N}^{\bullet}$ (10 pav.) - vibraciją sukeliantys PEEP prietaisai veikimo mechanizmu ir efektyvumu panašūs i FLUTTER bei ACAPELLA. Jie gali būti naudojami ne tik vertikalioje padetyje. Prietaisą sudaro kandiklis, žarnelè, lenktas vamzdelis, garso sklendès bei anga higienai. Teigiamo slègio svyravimai, reguliuojami kandikliu, išplečia kvẻpavimo takus, o juose susiformuojanti vibracija padeda išjudinti, suskystinti susikaupusi
12 pav. Autogeninio drenažo fazèse veikiami kvèpavimo takai

1) sekreto išjudinimo fazė 2) sekreto surinkimo fazè 3) sekreto pašalinimo fazè
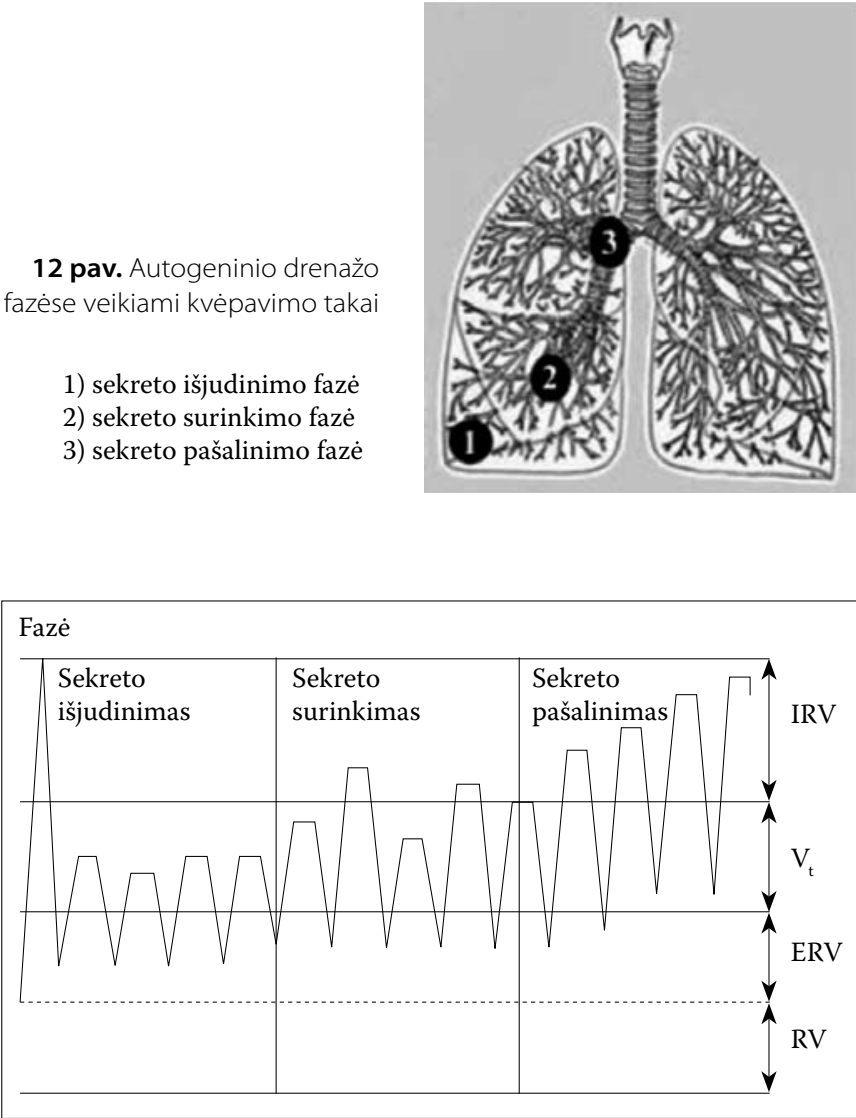

11 pav. Autogeninio drenažo metu naudojami plaučių tūriai

IRV - rezervinis ịkvèpimo tūris; $\mathrm{V}_{\mathrm{t}}$ - kvèpuojamasis tūris; ERV - rezervinis iškvèpimo tūris; RV - liekamasis tūris.

tirštą, lipnų sekretą bei palengvinti jo pasišalinimą. RCCornet skirtas pagerinti sekreto pasišalinimą iš bronchų, o RC- Cornet-N - iš sinusų. Šie prietaisai gali būti naudojami ir su vaistų purkštuvais.

Autogeninis drenažas - tai grupè kvėpavimo pratimų, skirtų išjudinti, surinkti bei pašalinti gleivingą, klampų sekretą iš plaučių, kvejpuojant įvairaus dydžio plaučiu tūriais. Skiriamos trys fazès - sekreto išjudinimo, surinkimo ir pašalinimo, atitinkamai naudojant mažo, vidutinio ir didelio plaučių tūrio pratimus (11 pav.). Pūtimas dideliu plaučių tūriu padeda šalinti sekretą iš viršutinių, vidutiniu ar mažesniu tūriu - iš apatinių, labiau periferinių kvẻpavimo takų (12 pav.).

Pratimus atlikti apmoko kvalifikuotas asmuo. Ikvepiama lètai pro nosị, kiek i̇manoma giliau, kvépavimas sulaikomas 3-4 sekundems ir iškvepiama lètai pro burną, be jejgos, pajuntant, kaip susitraukia pilvo sienos raumenys.

Sekreto išjudinimo fazèje oras iškvepiamas maksimaliai ir pilviniu kvẻpavimu įkvepiamas mažas jo kiekis. Pacientas gali išgirsti traškejjimą kvėpavimo takuose. Toks kvėpavimo ciklas atliekamas mažiausiai tris kartus, valingai valdant norą kosèti. Surinkimo fazèje, kai kvėpavimo takuose traškejjimas pradeda garsèti, atliekami vidutinio oro kiekio ịkvėpimai (kaip ir išjudinimo fazèje, 

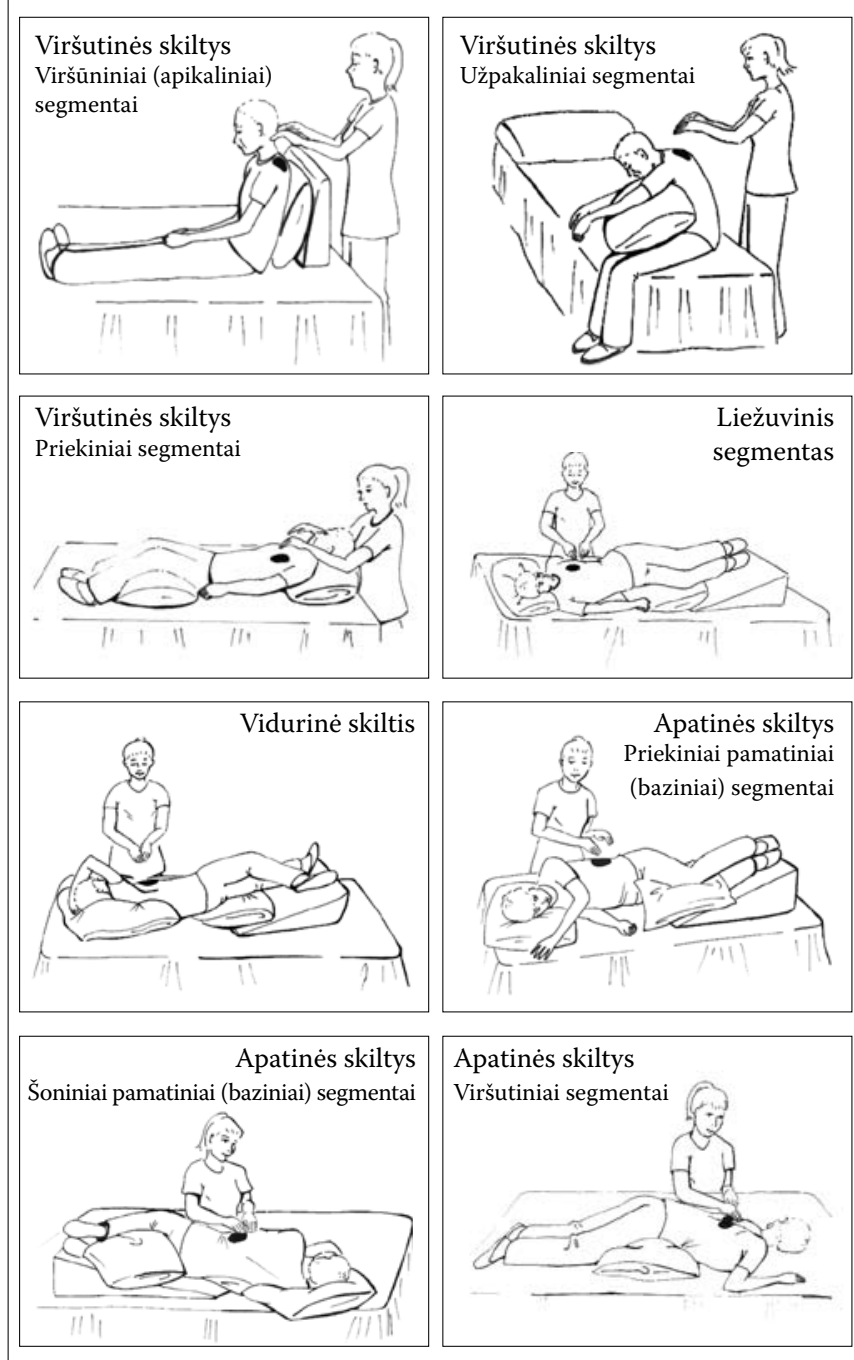

13 pav. Perkusijos taškai

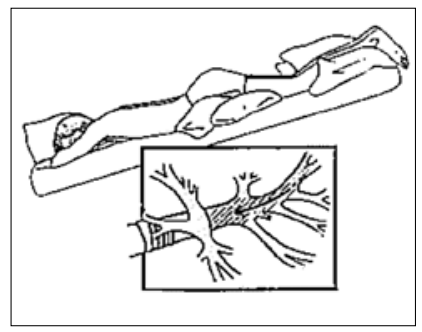

14 pav. Pozicinis taškas pagal bronchų anatomiją

http://www.urban-rehab.org/chest-physiotherapy-singapore.html

tik keičiasi įkvepiamo oro tūris). Pacientas turi pajausti, kad įkvèpto oro srovè pasiekia vidurinę krūtinès ląstos dalị. Šis kvėpavimo ciklas taip pat kartojamas mažiausiai tris kartus. Šalinimo fazejje, girdint garsų traškejjimą kvėpavimo takuose, atliekamas ilgas, lètas, kiek įmanoma gilesnis ịkvejpimas. Kartojama ne mažiau kaip tris kartus. Tada švelniai, bet su pastangomis išpučiamas oras (kartais to pakanka išjudintam sekretui pašalinti), jei reikia - pakosejjama. Autogeninis drenažas kartojamas tol, kol pavyksta pašalinti didžiąją dali susikaupusio sekreto arba pacientui pritrūksta jègų tęsti procedūrą. Padeda esant ryškiam švokštimui, polinkiui ị kvejpavimo takų kolapsą ir itin veiksmingas kenčiantiems nuo varginančio kosulio. Sunku autogeninị drenažą taikyti vaikams, nes metodo efektyvumas priklauso nuo suvokimo, sąmoningumo ir iddedamų pastangų.

\section{Aktyvių paciento pastangų nereikalingi bronchų sekreto šalinimo būdai}

Šie metodai taikomi esant sunkiai paciento būklei ar gretutinėms ligoms, ribojančioms aktyvių asmens pastangų reikalingu procedūrų atlikimą, CF paūmèjimo metu. Jie gali būti naudojami ir kaip ilgalaikès kompleksinès fizinès terapijos, gerinančios bronchų sekreto pasišalinimą, sudedamoji dalis kliniškai stabilios būklès CF ligoniams.

Krūtinès ląstos perkusija atliekama 15-20 sekundžių ir daroma ne trumpesnè kaip 5 sekundžių pertrauka, kad būtų išvengta plaučių funkcijos pablogejiimo sunkesniems pacientams. Procedūra atliekama medicinos personalo. Duomenų, kad mechaninè perkusija efektyvumu pranoktų atliekamą rankomis, nèra. Pagal tai, kurios sritys perkutuojamos, valosi skirtingi plaučiu segmentai (13 pav.). Kaip ir kiekvienas aprašytas metodas, taip ir šis, derinamas su kitomis procedūromis, padeda greičiau pasiekti laukiamų rezultatų. Krūtinès ląstos perkusiją pacientas gali atlikti sau pats ar padedamas artimujuç.

Pozicinis drenažas grindžiamas sunkio jègos principu - keičiant lovos/kūno padètị skatinamas sekreto judejjimas ir pasišalinimas iš kvėpavimo takų. Remiantis bronchų medžio anatomija sukurta 11 ịvairių lovos/kūno padèčių (14 pav.).

Kiekviena padetis padeda pagerinti sekreto pasišalinimą iš skirtingų plaučių skilčių ar segmentų (16 pav.), procedūra dažnai derinama su aktyvaus kvėpavimo ciklu, PEEP prietaisu ir krūtinès ląstos perkusija. Nusprendus taikyti pozicinị drenažą, turi būti individualiai parenkama padètis, kurioje esant sekretas pasišalina geriausiai (šiam tikslui sukurtos specialios lovos, kuo tikslesnei reikiamai kūno padèčiai išgauti; 15 pav.). Režimas keičiamas atsižvelgiant ì ligos eigą, simptomus, jų kaitą bei procedūros toleravimą. Kūdikiams ir suaugusiesiems, turintiems gastroezofaginị refliuksą, metodas gali būti pavojingas dèl padidejusios aspiracinès pneumonijos rizikos.

Kosulio reflekso sukèlimas naudojant „kosulio asistentą“ - tai saugus, patogus klampaus sekreto šalinimo iš kvèpavimo takų metodas, sukeliantis kosulio refleksą, tinkamas sunkiai atsikosintiems pacientams (sergantiems CF, lètine obstrukcine plaučių liga, raumenų ligomis, sąlygojančiomis kvėpuojamųjų raumenų silpnumą ir t. t.). Pro kaukę lèta srove tiekiamas teigiamo slègio oras staiga pakeičiamas ì neigiamo slègio oro tèkmę ir taip sukeliamas kosulio refleksas. Naudojantis šiuo prietaisu (17 pav.) išvengiama komplikacijų, galinčių kilti taikant invazines procedūras (pvz., aspiruojant 
mechaniškai ar bronchoskopu), atliekamas šalinti tąsiam sekretui, susikaupusiam kvėpavimo takuose. Prietaisų yra valdomų rankiniu būdu ir automatiškai.

Aukšto dažnio krūtinès ląstos vibracija - tai pasyvus kvėpavimo takų fizinès terapijos metodas, mechaniškai lengvinantis sekreto pasišalinimą iš plaučių. Tam naudojama liemenè, sujungta su oro srovès impulsų generatoriumi. Dažni ir staigūs oro srovès impulsai sukelia krūtinès ląstos vibraciją (18 a pav.). Jau yra sukurta, liemenė vibracines bangas generuojanti prie liemenės pritvirtintais dviem varikliukais, veikiančiais mažu bateriju pagrindu (18 b pav.). Ji patogesnè, nes yra mobili, neprijungta prie stacionarių prietaisu.

Liemenių sukeliama vibracija išjudina ir suskaido bronchų sekretą i mažesnes daleles, kurios judėdamos proksimalesnių kvejpavimo takų link palengvina atsikosẻjimą.

\section{CF PAŪMĖJIMO METU TAIKOMI METODAI}

Nèra įrodymais pagrịstų rekomendacijų, kokius metodus taikyti CF paūmejjus, tačiau vyrauja aktyvių paciento pastangų nereikalingi metodai. Pasirinkimas turi atitikti pablogejjusią paciento plaučiu funkciją, bendrąją būklę, sumažèjusį fizinio krūvio toleravimą. Reikia atsižvelgti ir ì kai kurias komplikacijas, lydinčias CF, bei fizinès terapijos ypatumus jų metu: 1) oras pleuros ertmèje; 2) kraujo atkosejjimas.

Paūmejjimų metu, kai oro pleuros ertmèje kiekis nedidelis, taikomi ịprasti fizinès terapijos metodai, tačiau patariama vengti veiklos, kuriai reikia rankų jègos, teigiamo slègio principu veikiančių priemonių naudojimo, mažinti pratimų intensyvumą. Reikètų tęsti aktyvaus kvėpavimo ciklus ar atlikti autogenini drenažą. Sekreto šalinimą gerinančios procedūros neturètų sukelti priepuolinio kosulio, bloginančio pneumotoraksu sergančio paciento būklę.
Jei ligonis atkosi skrepliu su kraujo priemaiša, taip pat taikomi îprasti fizinès terapijos metodai. Šiuo atveju prioritetiniai yra PEEP prietaisai, kurie padeda stabilizuoti kvėpavimo takus, tačiau patariama vengti naudoti vibraciją sukeliančius prietaisus. Siekiama kiek i̇manoma apsaugoti nuo priepuolinio kosulio.

Jei ligonis atkosi vidutini kiekị kraujo $(<250 \mathrm{ml} / 24$ val.), patariama vengti krūtinès ląstos perkusijos, vibraciją sukeliančių PEEP prietaisų bei liemenių naudojimo, kūno padèties, kai galva esti žemiau bendros kūno ašies. Intensyvus kosulys taip pat gali pabloginti situaciją, todèl patariama vietoj kosulio, skatinamo atliekant ịprastus kvèpavimo, pūtimo pratimus, pasistengti švelniai atsikrenkšti. Vengtinas intensyvus, bet skatintinas lengvas fizinis krūvis - pasivaikščiojimas ar važiavimas dviračiu, nedidinant širdies susitraukimų dažnio ir spaudimo plaučių arterijoje.

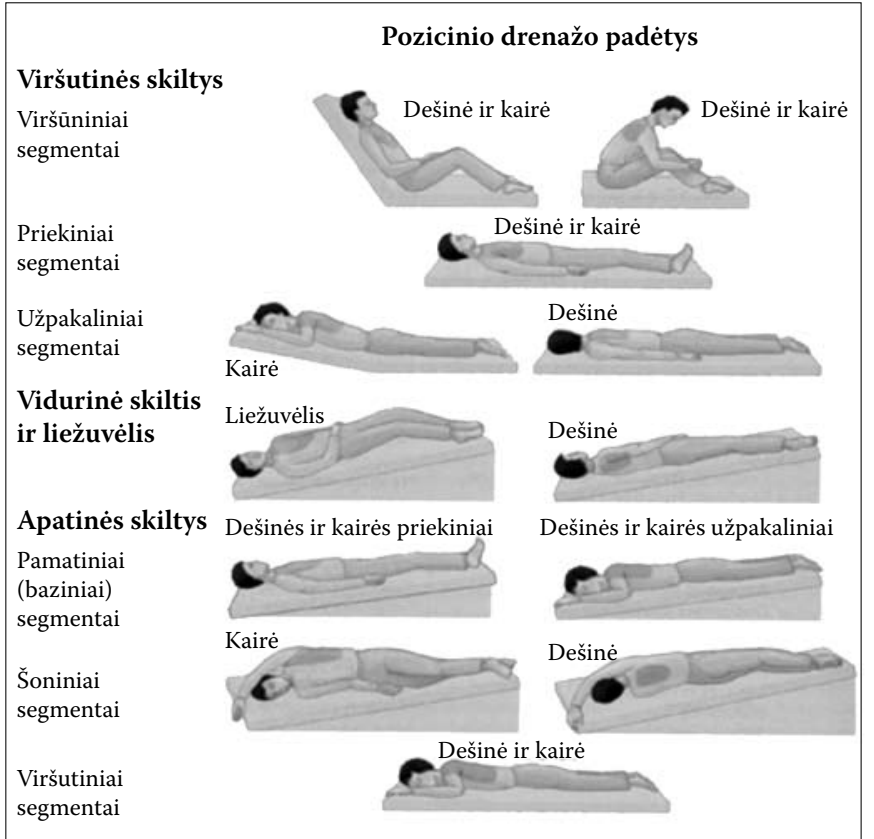

16 pav. Pozicinio drenažo padètys

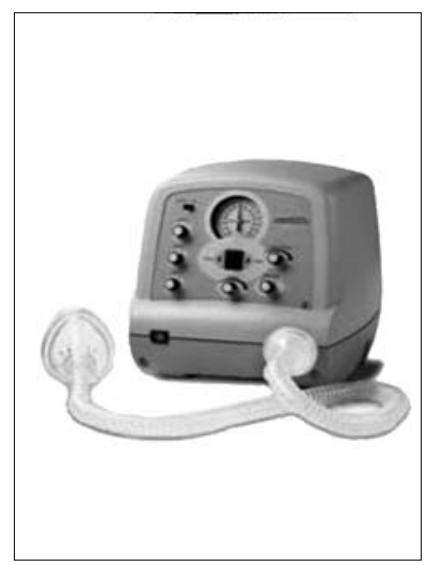

17 pav. "Kosulio asistentas"

http://www.anthemhs.com/Catalog/Online-Catalog-Product.aspx?pid=306

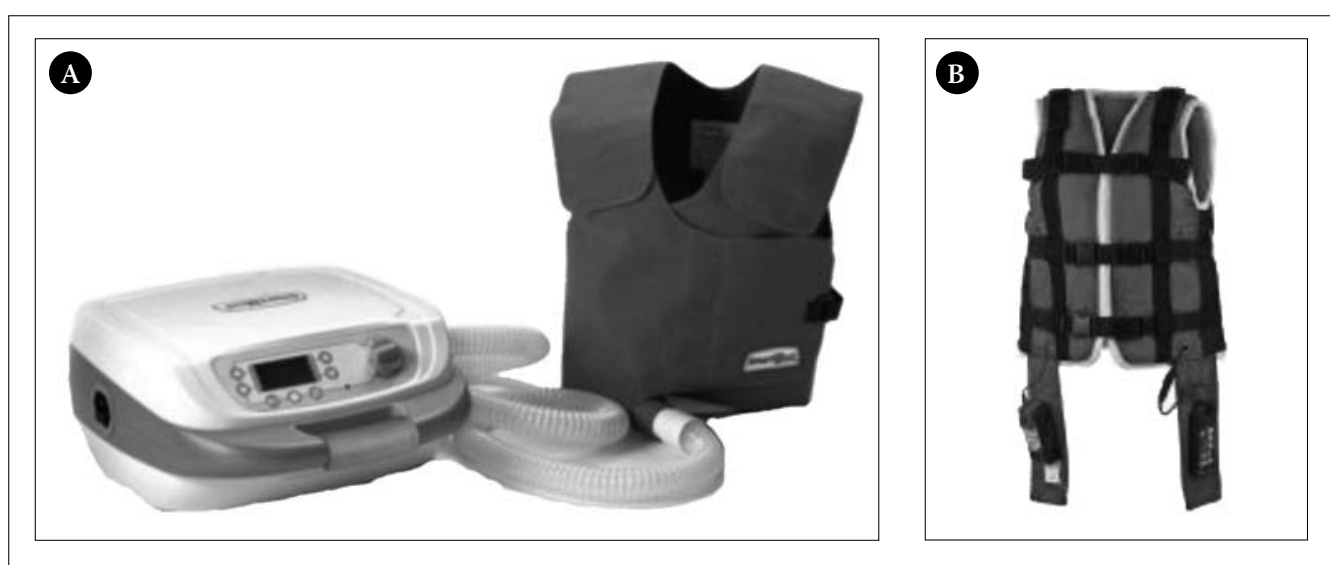

18 a, b pav. Aukšto dažnio krūtinès ląstos vibraciją sukeliančios liemenès

a) staigių oro srovių, sukeliančių krūtinės ląstos perkusijos ir vibracijos efektą, principu veikianti liemenė; b) tiesioginės vibracijos principu veikianti liemenè

a) http://www.sciencedirect.com/science/article/pii/S1526054207000085; b) http://www.oxycare.eu/ATEMTHERAPIE/Sekretolyse/ VibraVest-hochfrequente-Vibrations-Weste.html 
Jei kraujo atkosėjama daug (> $250 \mathrm{ml} / 24$ val.), sekreto pasišalinimą gerinančios procedūros netaikomas. Jei buvo atlikta bronchų arterijos embolija, reabilitacija pradedama nuo iprastuc kvėpavimo pratimų, palaipsniui itraukiant aktyvaus kvėpavimo ciklo bei autogeninio drenažo procedūras.

Gerẻjant CF paūmẻjimą patiriančio paciento būklei procedūros ir fiziniai pratimai sunkinami palaipsniui. Sunkiai sergantiems pacientams, atliekantiems fizinius pratimus, tikslinga tiekti papildomai deguonies, kad kraujyje būtų palaikomas pakankamas kiekis deguonies (kontroliuojant $\mathrm{SpO}_{2}$ ) ir nesumažètų kraujo įsotinimas deguonimi.

Tiek paūmèjimo, tiek komplikacijų metu sekreto skystejjimą skatina ir lengvina jo pasišalinimą tinkamas patalpos oro drèkinimas.

Esant sunkiai paciento būklei, kai susikaupęs sekretas sparčiai blogina kvėpavimą, ir nèra galimybių kitais, neinvaziniais, metodais sukelti sekreto pasišalinimą, galima išsiurbti ji mechaniškai (pro nosị, intubacini vamzdelį) ar bronchoskijos metu atliekant aspiraciją.

\section{APIBENDRINIMAS}

CF sergančio asmens gydymas yra kompleksinis, viena būtinų jo sudedamųjų dalių - fizinès terapijos metodai. Todèl tiek ligai esant stabiliai, tiek paūmèjusiai, kartu su vaistais svarbu parinkti ir taikyti individualuc bei veiksmingą nemedikamentinị bronchų sekreto šalinimo metodą ar jų derinius. Esant stabiliai ligai, dažniausiai taikomi aktyvių paciento pastangų reikalingi fizinès terapijos metodai, ligos paūmèjimo metu - vyrauja nereikalingi aktyvių pastangų. CF ligoniams individualiai parinkti ir reguliariai taikomi sekreto šalinimą gerinantys fizinès terapijos metodai lengvina respiracinius simptomus, gali retinti kvėpavimo takų infekcijų, jų sukeliamų komplikacijų bei ligos paūmẻjimų dažnumą.

\section{NONPHARMACOLOGIC METHODS FOR REMOVAL OF BRONCHIAL SECRETION IN PATIENTS WITH CYSTIC FIBROSIS}

\section{VIRGINIJA KALINAUSKAITE், KĘSTUTIS MALAKAUSKAS \\ DEPARTMENT OF PULMONOLOGY AND IMMUNOLOGY LITHUANIAN UNIVERSITY OF HEALTH SCIENCES}

Key words: cystic fibrosis, airway, physical therapy techniques. Summary. This article discusses the nonpharmacologic methods of disposal of bronchial secretion in patients with cystic fibrosis. Methods are divided into active patient efforts requiring and do not requiring. With a steady course of the disease becomes priorities for the active efforts requiring methods. Exacerbation of cystic fibrosis at the time dominated by an active effort not requiring methods.

\section{LITERATŪRA}

1. Agent P, Morrison L, Prasad A. Standards of Care and good clinical Practice fot the Physiotherapy Management of Cystic Fibrosis. Cystic Fibrosis Trust Association of Chartered Physiotherapists in Cystic Fibrosis, 2011; 2nd Ed; 15-20.

2. Bradley JM, Moran FM, Elborn JS. Evidence for physical therapies (airway clearance and physical training) in cystic fibrosis: An overview of five Cochrane systematic reviews. Resp Med 2006; 100: 191-201.

3. Fink JB. Forced Expiratory Technique, Directed Cough, and Autogenic Drainage. Respir Care 2007; 52: 1210-23.

4. Yu H, Hanes M, Chrisp CE, Boucher JC, Deretic V. Microbial Pathogenesis in Cystic Fibrosis: Pulmonary Clearance of Mucoid Pseudomonas aeruginosa and Inflammation in a Mouse Model of Repeated Respiratory Challenge. Infect Immun 1998; 66: 280-8.

5. Lester MK, Flume PA. Airway-Clearance Thepary Guidelines and Implementation. Respir Care 2009; 54: 733-53.

6. McCool FD, Rosen MJ. Nonpharmacologic airway clearance therapies: ACCP evidence-based clinical practice guidelines. Chest 2006; 129: 250-9.

7. Mcilwaine M., Van Ginderdeuren F. Physiotherapy for people with Cystic Fibrosis: from infant to adult. 2009; 4th Ed: 5-26.

8. Pisi G, Chetta A. Airway clearance therapy in cystic fibrosis patients. Short review; Acta Biomed, 2009; 80: 102-106.

9. Ratjen FA. Cystic Fibrosis: Pathogenesis and Future Treatment Strategies. Respir Care 2009; 54: 595-602.

10. Scherer TA, Barandun J, Martinez E, Wanner A, Rubin EM. Effect of High-Frequency Oral Airway and Chest Wall Oscillation and Conventional Chest Physical Therapy on Expectoration in Patients With Stable Cystic Fibrosis. Chest 1998; 113: 1019-27. 